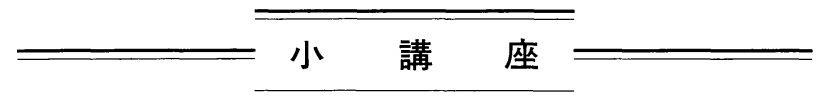

農業気象 (J.Agr. Met.) 43 (2): 157-158, 1987

\title{
温度標準と校正法
}

\author{
竹 下 俊 二
}

（国立公害研究所）

すでに，本講座で紹介されているように，最近の目覚 しい技術革新によって各種の優れた温度センサか開発さ れている。従って, 日頃温度計測に携わる者は, 測定時 間の短縮, 精度の向上, 簡便さなどに随分恩恵を受けて いる。例えば， $1 / 1000^{\circ} \mathrm{C}$ の分解能をむつ水晶温度セン サが市販されてきている。てのような温度センサ屯含め て常用の温度計の確度を決定することは, それらの精度 の維持管理上，極めて重要なととである。こてでは，温 度標準のトレーサビリティとともに温度センサの校正法 について紹介する。

\section{1. 国際実用温度目盛}

国際実用温度目盛 (International Practical Temperature Scale)は，国際的に共通で実用的な温度目 盛を取り決めるために作られた目盛であり，自然科学の 分野はむとより広く一般に使われている全ての温度を定 義するむのである。そして, 温度を数值で表す際に基本 となる熱力学温度を最むよく近似しているてとと熱力学 温度の測定法よりも再現性に優れている特徵をむってい る。

制度的には，1927 年に制定され，1968 年国際実用温 度目盛 (IPTS-68) 及び 1976 年暫定目盛を経て今日に 至っている。IPTS-68 は，熱力学温度で定義される物 理量と異なり, 水の三重点, 水の沸点, 金の凝固点など 13 個の熱的に安定な状態に対応する定点值であるとと あに，測定計器と温度の補間法が規定されている（ただ し, 水の三重点は熱力学温度及び IPTS-68 の共通の定 義定点となっている)。

な拉， $0{ }^{\circ} \mathrm{C}$ 以下の低温域の温度目盛については従来, 誤差の存在が指摘されていたが, 最近の温度計測技術の 進展や温度補間法についての検討が行われた結果, 測定 精度の向上が図られ, 1975年の改訂目盛の実現に至った。

\section{2. 温度標準のトレーサビリティ}

温度計測器交び温度センサは, 校正や検定を通して常
に精度の管理を行わなければならない。この精度が国際 実用温度目盛とどのような関係にあるかを明確にトレー スできるととを一般にトレーサビリティと呼ぶ。実際に は, 実用の温度計から順次より精度の高い温度計へと進 み，最終的に国際実用目盛に到達することになる。図 1 に温度標準へのトレーサビリティの流れを示す。

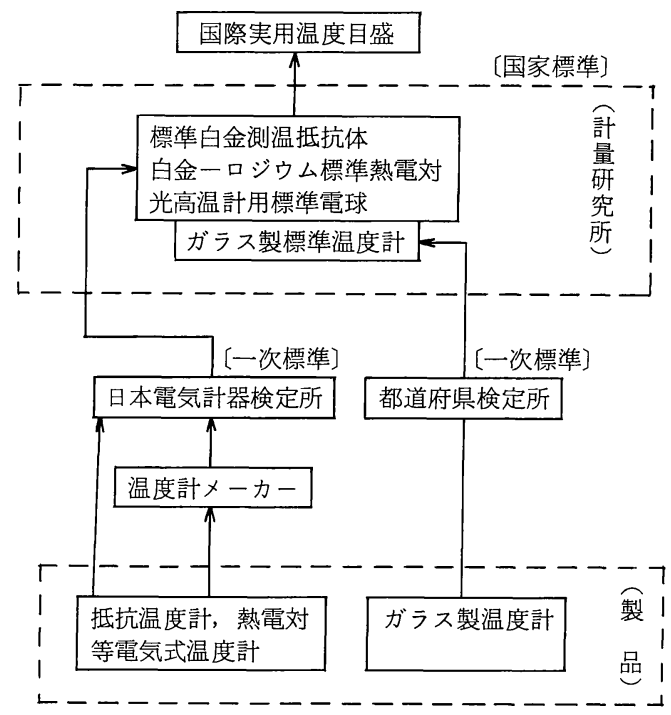

図 1 温度標準へのトレーサビリティの流れ （計測技術研究会編，1980）

\section{3. 温度センサ及び温度計測器の校正法}

温度センサの校正は，精度 (確度)別に，（1） $2 / 100^{\circ} \mathrm{C}$ 以下, (2) $2 / 100 \sim 1 / 10^{\circ} \mathrm{C}$ ，（3） $1 / 10^{\circ} \mathrm{C}$ 以上, に大別 できる。

（1）は国家標準的精度を必要とするむので定点法（水 の三重点，水の沸点，金，銀などの凝固点）か該当する。 しかし, 定点装置の運転, 操作及び保守管理などが複雑 であるとともに，時間がかかるのと全体的なノウハウが 必要なととから一般的ではない。最近普及してきた水晶 
温度計(精度 : $\pm 0.02^{\circ} \mathrm{C}$ )など(1)の精度近辺の校正には, 設備費はかさむが測定操作が簡単な方法として NQR 標 準温度計 (精度 : $\pm 0.005^{\circ} \mathrm{C}$ ) 及び計量研型恒温水槽(温度 分布： $\left.\pm 0.004^{\circ} \mathrm{C}\right)$ の組み合わせが適している。

(2)，(3)の領域は, 比較法と呼ばれる校正法を用いて ユーザー自ら比較的容易に実施できる。乙の方法は，校

表 1 公立検定機関の校正確度 （二木・村上, 1981）

\begin{tabular}{|c|c|c|c|}
\hline 種 & 類 & 温度範囲 $\left({ }^{\circ} \mathrm{C}\right)$ & 最高精度 $\left({ }^{\circ} \mathrm{C}\right)$ \\
\hline \multirow{4}{*}{$\begin{array}{c}\text { ガ } \\
\text { ラ } \\
\text { ス } \\
\text { 製 } \\
\text { 温 } \\
\text { 度 } \\
\text { 計 }\end{array}$} & $\begin{array}{l}1 \text { 目盛の值 } \\
0.1^{\circ} \mathrm{C} \text { 以下 }\end{array}$ & $\begin{array}{c}0 \sim 100 \\
-50 \sim 0, \quad 100 \sim 300 \\
300 \sim 360\end{array}$ & $\begin{array}{l} \pm 0.03 \\
\pm 0.05 \\
\pm 0.1\end{array}$ \\
\hline & $\begin{array}{c}1 \text { 目盛の值 } \\
0.2^{\circ} \mathrm{C}\end{array}$ & $\begin{array}{c}0 \sim 100 \\
100 \sim 200 \\
-50 \sim 0, \quad 200 \sim 300 \\
300 \sim 360\end{array}$ & $\begin{array}{l} \pm 0.05 \\
\pm 0.06 \\
\pm 0.1 \\
\pm 0.15\end{array}$ \\
\hline & $\begin{array}{c}1 \text { 目盛の值 } \\
0.5^{\circ} \mathrm{C}\end{array}$ & $\begin{array}{c}0 \sim 100 \\
-50 \sim 0, \quad 100 \sim 300 \\
300 \sim 360\end{array}$ & $\begin{array}{l} \pm 0.1 \\
\pm 0.2 \\
\pm 0.3 \\
\end{array}$ \\
\hline & $\begin{array}{c}1 \text { 目盛の值 } \\
1^{\circ} \mathrm{C}\end{array}$ & $\begin{array}{l}-50 \text { 未満 } \\
-50 \sim 200 \\
200 \sim 360 \\
360 \sim 450 \\
450 \sim 600 \\
\end{array}$ & $\begin{array}{l} \pm 0.5 \\
\pm 0.2 \\
\pm 0.3 \\
\pm 1.0 \\
\pm 2.0\end{array}$ \\
\hline \multirow[b]{2}{*}{$\begin{array}{l}\text { 抵抗 } \\
\text { 温度計 }\end{array}$} & 抵抗温度計 & $-200 \sim 500$ & \pm 0.05 \\
\hline & $\begin{array}{l}\text { 白金測温抵 } \\
\text { 抗体 }\end{array}$ & $\begin{array}{c}-260 \sim 630 \\
\text { 定義定点 }\end{array}$ & $\begin{array}{c} \pm 0.02 \\
\pm 0.01 \sim 0.002\end{array}$ \\
\hline \multirow[b]{2}{*}{$\begin{array}{l}\text { 熱電対 } \\
\text { 温度計 }\end{array}$} & 熱電温度計 & $0 \sim 1500$ & \pm 0.1 \\
\hline & PR 熱電対* & $\begin{array}{r}0 \sim 1100 \\
1100 \sim 1500 \\
\text { 定義定点 }\end{array}$ & $\begin{array}{l} \pm 1.0 \\
\pm 3.0 \\
\pm 0.2\end{array}$ \\
\hline
\end{tabular}

*温度センサとしての校正精度
正しようとする温度センサと校正済みの一次標準器（後 述）とを恒温槽内で同一温度に保ち，それぞれの示度を 比較校正しょうとするあのである。乙の場合，校正精度 を決定する重要な因子は恒温槽内温度の一定性，一様性 のレベルであるのでこの点に最も留意した装置を備えな ければならない。校正対象となる温度センサは熱電対, ガラス温度計，抵抗温度計などがあり，恒温槽は市販品 のうち，精密型を用いればよい。

手元に一次標準器を設置する場合は, 国家標準 (工業 技術院計量研究所）に準ずる機関として設立されている 日本電気計器検定所で表 1 の各センサの校正，検定を受 けるとよい。また，ガラス温度計に限っては公的機関之 して都道府県検定所が設けられているので，そてで校正 を済ませたものを一次標準とする。表 1 亿公立検定機関 の校正確度を示す。

\section{参考文献}

二木久夫・村上孝一, 1981 : 温度センサ. 日刊工業新聞 社, 205 210

計測技術研究会編, 1980 : 温度計測技術 - 精度維持管理

資料集. 経営開発センター出版部, $12 \sim 18$

大手 明 - 岩岡秀人 - 三井清人 - 桜井弘久 - 稲葉 章, 1977 ：NQR 精密温度計. 第 16 回計測自動制御学会 学術講演会予稿集, 2507

桜井弘久, 1980 : 低温度領域におりる国際温度目盛. 応 用物理， $\mathbf{4 9}, 259 \sim 265$

桜井弘久, 1986 ：温度標準 - IPS. 熱測定, 13，224～ 227 